\title{
ICT Literacy and Readiness for Computer Based Test Among Public Secondary School Students in Anambra State
}

\author{
Cornelius A. Ukwueze Ph.D \\ Associate Professor \\ Department of Mass Communication \\ Nnamdi Azikiwe University, Awka, Anambra State, Nigeria \\ E-mail: coliinsaghadi@yahoo.com,ca.ukwueze@unizik.edu.ng \\ Uzoagba, Ogochukwu Nneka \\ Department of Mass Communication \\ Nnamdi Azikiwe University, Awka, Anambra State, Nigeria \\ E-mail: ogochukwunneka@gmail.com
}

\begin{abstract}
Among the significant influences of the new information and communication technologies (ICTs) on the educational system is the emergence of the computer-based test (CBT) which now exists side by side, and in some instances, has replaced the traditional pen and paper method of examination. The introduction of CBT in the JAMB Unified Tertiary Matriculation Examination (UTME) and its use in post-UTME tests by various higher institutions have now made ICT literacy critical for one's academic progression beyond the secondary school level. Therefore, this study examined readiness for Computer-Based Tests (CBT) among public secondary school students in Anambra State, Nigeria in terms of acquiring the requisite ICT literacy. Situated within the framework of the Diffusion of Innovations Theory, the study adopted the survey method.A sample of 659 respondents was selected from public secondary school students in the state. Data analysis employed simple percentages and Pearson chi-square test. Findings showed that to a significant extent, students in public secondary schools in Anambra State were aware of the relevance of ICT literacy for their participation in external examinations. However, a significant number of the students were yet to take steps to acquire ICT literacy in readiness for computer-based tests (CBTs). The rate of actual readiness for such tests was low among the students. Factors influencing readiness for CBT among the students were gender, age, school type (boys, girls or coeducational), school location (urban versus rural), school-based computer training, availability of computer at students' homes and attending of outside-school computer coaching. It was concluded that many students in Anambra State public schools who participate in computer-based tests (CBTs) appear to acquire the required ICT skills only after they have left school, a situation that may not be very healthy given that early preparation is more likely to enhance better performance. The study recommended, among others, that schoolbased computer training should be enhanced by way of procurement of equipment and employment of computer literate teachers in order to enable schools provide such training on a regular basis to students which will enhance their readiness for computer-based tests (CBT).
\end{abstract}

Keywords: Computer Based Test (CBT), Information and Communication Technology (ICT), ICT Literacy, External Examination, Public Secondary Schools, Secondary School Students, Readiness.

DOI: $10.7176 / \mathrm{NMMC} / 97-01$

Publication date:August $31^{\text {st }} 2021$

\section{Introduction}

The introduction of the Computer-Based Test (CBT) as a method of administering examinations in Nigeria's school system has brought a new era where ICT literacy becomes a relevant skill for effectively participating in examinations (Abubakar \& Adebayo, 2014; Adepoju, 2016). Instructively, the examinations that are currently involved in this innovation are very critical to academic and career advancement of students. As far as secondary school students are concerned, these examinations principally are the Unified Tertiary Matriculation Examination (UTME) and Post-UTME conducted by the Joint Admissions and Matriculation Board (JAMB) and tertiary institutions respectively (JAMB, 2015; Adepoju, 2016).Against this backdrop, this study examined the extent of students' readiness for the examinations by way of acquiring the requisite ICT literacy.

Examination or test is an important element in the formal school system. According to Alabi, Issa and Oyekunle (2012), it is an instrument used for making assessment on teaching and learning. In schools, examination or test is used to measure what learners have learnt at the end of a class, term, semester or session. It provides the benchmark for promoting students, for ensuring that they have met the required standards on their way towards being certified for completing school or a programme of study. It is also used to enter certain occupations, or as a method for selecting students for entry into tertiary institutions. Examination or test has to do with merit and worth of the data as applied to a specific use or context (Alabi, Issa \& Oyekunle, 2012; 
Abubakar \& Adebayo, 2014).

In regard to mode of examinations, traditionally, Paper-Based Test (PBT) has been the dominant practice, and it involves the basic practice of writing, drawing or making any other mark on paper as a way of providing answers to exam questions (Adepoju, 2016). Till today, it remains the dominant approach in the school system in Nigeria (Nwoke, Osuji\&Agi, 2017).

Nevertheless, the Paper-Based Test (PBT) approach to examinations has been attributed with many challenges. With reference to examination bodies like WAEC and JAMB, Alabi et al. (2012) identifies the problems of the PBT to include:

...tedious processes as the examination was conducted at various and distant centres simultaneously and marked manually; high risks of accidents during travels by both the staff involved and the prospective students for the paper examination; cost of conduct of the examination on the part of the examination bodies including honorarium for invigilators, coordinators, markers, collators and other allied staff; subjective scoring and plausible manipulation of results; late release of results and missing grades; bank draft method of payment by candidates riddled by fraud, loss of money, stress and trauma. (p.68).

It is the application of technology towards solving the challenges of the Paper-Based Test (PBT) that gave birth to what is termed Computer-Based Test (CBT). Also known as Computer-Based Assessment, eExamination/Assessment, Computerized Testing and Computer-Administered Testing, this is a method of administering examinations in which the responses are electronically recorded, assessed, or both. CBT enables exam authorities to design, schedule, deliver, and report on surveys, quizzes, tests, examinations and other forms of testing. "It may be a stand-alone system or a part of a virtual learning environment, possibly accessed via the World Wide Web" (Adepoju, 2016, p.2). The merit of this method of examination primarily lies in its electronic nature which implies that it is substantially free from some of the limitations imposed by time and distance as seen with Paper-Based Test (PBT). The advantages of the use of Computer-Based Test (CBT) have been noted in literature. The main advantages include: lowering long-term costs, instant feedback to exam candidates, increased productivity and low operational variability, accommodation of candidates with special needs (deaf and dumb, blind etc), and improved impartiality (as computerized marking does not "know" the students so neither favours nor makes allowances for errors). Another important merit of CBT is minimization of malpractice including impersonation and cheating (Abubakar \& Adebayo, 2014; Okoronkwo, 2015).

Many universities have since adopted the approach for conducting entrance examinations (Post-UTME) as well as some of their internal examinations. But among the public examination bodies administering examinations to secondary school students/secondary school leavers, it is the Joint Admissions and Matriculation Board (JAMB) that has fully integrated the approach. JAMB had conducted its examinations exclusively via the Paper and Pencil Test (PPT) method until 2013 when it experimented with the Computer-Based Test (CBT). That year, candidates were permitted to choose whether to take the exam via the traditional PPT or the novel CBT. Eventually, in 2015, JAMB completely migrated from the Paper and Pencil Test (PPT) to CBT. This, according to the Board, was due to some factors associated with the PPT including security challenges, high cost of producing writing materials, high cost of transporting materials, high incidences of examination malpractice, and complexity, tediousness and slowness in result processing (JAMB, 2015).

Basically, secondary school students may acquire ICT literacy either through ICT training offered in their schools or the one offered by ICT training centres. Very few wealthy parents can also arrange for private training for their children, and such families usually have computers at home (Adebowale, Adewale \& Oyeniran, 2010; Bakare, 2017). Nevertheless, as noted by Apagu and Wakili (2015), school-based training remains the most promising strategy for achieving mass ICT literacy among young people. This integrates ICT training in the curriculum, meaning that it becomes accessible to the mass of the population and that the students do not have to be subjected to the stress and time-taking rigour of engaging in such training outside the school hours (Apagu \&Wakili, 2015; Bakare, 2017).

Nevertheless, the concern has been whether secondary schools in Nigeria have the capacity - in terms of facilities and human resources - to effectively offer ICT training. Literature shows that the state of facilities in these schools, especially public schools which the bulk of the population attend, is far from being satisfactory (Osunwusi \& Abifarin, 2013; Apagu\&Wakili, 2015; Bakare, 2017). In addition, there is also dearth of ICT teachers in most of such schools. All these raise the question as to how possibly students who attend these schools could acquire the needed ICT training in readiness for the Computer-Based Test (CBT) examinations awaiting them in the near future.

\section{Statement of the Problem}

The adoption of the Computer-Based Test (CBT) by the Joint Admissions and Matriculation Board (JAMB) and tertiary institutions as the method of administering examinations for entry into higher schools has meant that ICT 
literacy has become a sine qua non for would-be candidates of these examinations majority of whom are secondary school students (Fagbola, Adigun \& Oke, 2013; Joshua \&Ikiroma, 2016; Njoku \& Oriaku, 2016; Nwoke, Osuji, \& Agi, 2017). Consequently, failure to gain this literacy places one in a disadvantage position visà-vis success in these examinations.

However, secondary schools in Nigeria - particularly government schools - have been noted to be generally inadequate in terms of ICT facilities and even ICT teachers to be able to efficiently offer ICT training to their students (Osunwusi \& Abifarin, 2013; Nwanze, 2014;Ogwo, Maidoh \& Onwe, 2015). This is in the face of the growing place of ICTs in the world and the concomitant need for individuals to acquire the skills required to use them.

Also, the CBT approach to examination is still relatively new in Nigeria. Its first general use by a public examination body conducting exams for secondary school leavers (i.e. JAMB) was in 2015 (JAMB, 2015; Adepoju, 2016). Therefore, like every new innovation, its awareness may take some time to spread among the population, meaning that some students may not be exactly aware of the ICT requirement of these external exams well ahead of the time they are to take them. This may be more likely in rural areas where adoption of innovations is basically slower (Griffin, 2000; Osunwusi \& Abifarin, 2013). Such situation could imply that the students may not be exactly ready for the examinations. This study therefore investigated the level of ICT literacy and readiness for CBTs among public secondary schools in Anambra state, South East Nigeria.

\section{Objectives of the Study}

The purpose of this study was to examine ICT literacy and readiness for Computer-Based Tests (CBT) among public secondary school students in Anambra State. The specific objectives were:

i. To assess the extent students in public secondary schools in Anambra State are aware of the relevance of ICT literacy for their external examinations.

ii. To find out the extent students have taken steps to acquire ICT literacy in readiness for the examinations.

iii. To ascertain the proportion of the students that have already acquired the ICT literacy needed for external examinations.

iv. To determine factors that affect the students' acquisition of such ICT literacy.

\section{Research Questions}

Based on the foregoing objectives, the following research questions were formulated to guide the study:

1. To what extent are students in public secondary schools in Anambra State aware of the relevance of ICT literacy for their external examinations?

2. To what extent have the students taken steps to acquire ICT literacy in readiness for the examinations?

3. What proportion of the students has already acquired the ICT literacy needed for the external examinations?

4. What factors affect the students' acquisition of such ICT literacy?

\section{Literature Review and Theoretical Framework}

Some empirical literature were reviewed on the level ICT literacy among teachers and students in Nigerian schools as well as the merits and the challenges of bthe adoption of CBT for public examinations in Nigeria.

Eze and Akubugwo (2016) evaluated the integration of computer/ICT education by teachers in junior secondary schools in the three educational zones in Abia State. Research questions were formulated based on the comprehensiveness and adequacy of the curriculum, availability of computer/ICT facilities, and qualified and proficient teachers for effective teaching and learning. Forty-five out of the 108 junior secondary schools offering computer/ICT education were selected via simple random sampling technique. A total of 69 teachers were involved in the study. The data collected was analysed with percentage and mean score. Findings showed that computer education curriculum was adequate but the main objective of introducing this programme in the junior secondary schools had not been fully achieved as a result of lack of computer/ICT laboratory and incompetent teachers that resulted to poor teaching and learning method. This study overlaps with the present research in the area of ICT learning in secondary schools; nevertheless, while the above study was concerned with teachers who impart the ICT literacy, the present research is concerned with students who should acquire the literacy.

Ubulom and Wokocha (2012) studied readiness and acceptability of computer-based test (CBT) for postuniversity matriculation examinations (PUME) among urban and rural senior secondary school students in Rivers State. The research design was descriptive survey research. The sample size for the study comprised 600 final year students drawn from 60 secondary schools in 12 LGAs from the 3 senatorial zones of Rivers State, using purposive sampling to take care of location variables. A structured questionnaire (with reliability of .88) was used to collect data and a total number of 450 copies of the questionnaire were retrieved, which were analysed using mean, standard deviation and independent t-test. The results indicated that the level of readiness 
and acceptability was moderate on the part of students from urban areas of the state but their counterparts in the rural areas were lagging behind. It was concluded that Rivers State students, both in urban and rural areas, if given the enabling environment and support, would build high level of readiness and acceptability of the innovation in learning assessment, whether for JAMB UTME or Post-UTME. This study overlaps with the present research in the area of ICT literacy and students' readiness for CBT examinations; however, while its area of focus was Rivers State, the present research focuses on Anambra State.

Fehintola (2018) examined the challenges of CBT among students in Nigerian educational system. The study made use of descriptive research design of survey type and the population of interest was the senior secondary school students that had experienced CBT. The sample was made up of 330senior secondary school students that had experienced CBT assessment. Simple random sampling technique was used to select the participants. Data were collected through the use ofa questionnaire tagged "Challenges of CBT among Students in Nigerian Educational System" with reliability coefficient of 0.79 . The findings showed that students took CBT assessment amidst lot of challenges such as inadequate facilities, poor power supply, lack of computer technical knowhow, problems of far distance and insecurity of examination materials. The study concluded that CBT, despite its unique advantages, is still confronted by a lot of challenges. This study intersects with the present research in the area of CBT examination; however, while it focused on the challenges confronting this method of testing, the present effort differs in the sense of being particularly interested in how secondary school students' acquisition of ICT literacy helps their preparedness for such examinations.

\section{Theoretical Framework}

\section{Diffusion of Innovation Theory}

The Diffusion of Innovation Theory seeks to explain how, why, and at what rate new ideas and technology spread through cultures" (Lewis, 2009, p.99). Though its origin could be credited to contributions from different scholars across diverse fields, the theory was popularised by Everett Rogers, a professor of rural sociology in his 1962 book Diffusion of Innovations. He describes diffusion as the process by which an innovation is communicated through certain channels over time among the members of a social system. Summarising the essentials of the theory, McCarthy (1998) writes:

It originated in communication to explain how, over time, an idea or product gains momentum and diffuses (or spreads) through a specific population or social system. The end result of this diffusion is that people, as part of a social system, adopt a new idea, behaviour, or product. Adoption means that a person does something differently than what they had previously (i.e., purchase or use a new product, acquire and perform a new behaviour, etc.). The key to adoption is that the person must perceive the idea, behaviour, or product as new or innovative. It is through this that diffusion is possible (p.78).

The Diffusion of Innovation Theory is considered most apt for building a theoretical framework for this study. This assertion is premised on the fact that Computer-Based Test (CBT) is a relatively new innovation in Nigeria. In fact, its first general application by any of the public examination bodies administering exams for secondary school students/ leavers in Nigeria (i.e. WAEC, NECO, JAMB, NABTEB) was in 2015 when JAMB made it the standard examination for mode for its yearly UTME (JAMB, 2015; Joshua \& Ikiroma, 2016). Being new, therefore, it presumably may still be undergoing its adoption (diffusion) process among Nigerians, and this adoption process has as one of its most vital element the acquisition of the requisite ICT skills.

Against this backdrop, individual secondary school students, depending on how early or late they are in adopting this technology (through acquiring ICT skills), may, based on the Diffusion of Innovation Theory, be included among the innovators, the early adopters, the early majority, the late adopters or the laggards. Basically, it may be expected that while some students may foresightedly acquire the skills well ahead of time, others may be taken unawares and only rely on a fire brigade approach.

Methodology: The study adopted mixed method of quantitative (survey) and qualitative (Focus Group Discussion) research designs. The sample size for the survey aspect of the study was determined by reference to the sample sizes as computed by Krecjie \& Morgan (1972). Since the study population is up to 100,000 and less than 500, 000, the sample size became 659 (at 5\% error margin and 99\% confidence level). The sampling procedure was multi-stage in approach which involves following a series of logical steps in selecting sample units from different categories of schools in the three Senatorial Districts of the State. The instrument for data collection was the questionnaire and survey data were analyzed in tables, percentages and Chi-square.

For the FGD, the sample size was 18. The 18 students formed three focus groups; one group for each of the three Senatorial Districts. The FGD Guide was the instrument for data collection in the qualitative segment and analyzed thematically. 


\section{Survey Data Presentation and Analysis}

The survey data are segmented into three as follows: response rate, demographic variables, respondents' awareness of the relevance of ICT literacy for computer-based external examinations, respondents' acquisition of ICT literacy in readiness for CBT, and factors influencing respondents' readiness for CBT.

\section{Response Rate}

Table 1.

Response Rate

\begin{tabular}{lcc}
\hline & Frequency & Percentage \\
\hline No. Recovered & 624 & $94.7 \%$ \\
No. Not Recovered & 35 & $5.3 \%$ \\
\hline Total & $\mathbf{6 5 9}$ & $\mathbf{1 0 0 \%}$ \\
\hline
\end{tabular}

Table 1 shows that out of the 659 copies of the questionnaire distributed among the respondents, 624 representing $94.7 \%$ were recovered, while 35 representing $5.3 \%$ were not. Thus, $94.7 \%$ response rate was recorded as against $5.3 \%$ casualty rate.

\section{Demographic Variables}

Five demographic variables were measured viz gender, age, class of study, type of school and location of school. Data collected in that regard are presented in Table 4.2 below.

Table 2.

Demographic Variables

\begin{tabular}{|c|c|c|c|}
\hline VARIABLES & ITEMS & FREQUENCY & PERCENTAGE \\
\hline \multirow{3}{*}{ Gender } & Male & 274 & $43.9 \%$ \\
\hline & Female & 350 & $56.1 \%$ \\
\hline & Total & 624 & $100 \%$ \\
\hline \multirow{4}{*}{ Age Bracket } & $14-17$ & 517 & $82.9 \%$ \\
\hline & 18 and above & 107 & $17.1 \%$ \\
\hline & Total & 624 & $100 \%$ \\
\hline & SS II & 338 & $54.2 \%$ \\
\hline \multirow[t]{2}{*}{ Class } & SS III & 286 & $45.8 \%$ \\
\hline & Total & 624 & $100 \%$ \\
\hline \multirow{4}{*}{ Type of School } & Boys' School & 171 & $27.4 \%$ \\
\hline & Girls' School & 187 & $30.0 \%$ \\
\hline & Coeducational School & 266 & $42.6 \%$ \\
\hline & Total & 624 & $100 \%$ \\
\hline \multirow{2}{*}{$\begin{array}{l}\text { Location of } \\
\text { School }\end{array}$} & Urban area & 368 & $59.0 \%$ \\
\hline & Rural area & 256 & $41.0 \%$ \\
\hline
\end{tabular}

Table 2 presents the demographic data of the respondents. It shows that $43.9 \%$ of the respondents are male as against $56.1 \%$ that are female. This implies that majority of the respondents were female students. Further, $82.9 \%$ were 14 - 17 years, while $17.1 \%$ were 18 years and above, which points to the fact that most students now complete their secondary education before they become 18 . Also, while $54.2 \%$ of the respondents were in SS II, 45.8\% were in SIII. This difference may be explained by the fact that number of students in a school may tend to reduce as classes progress given that students may drop out or change school. Importantly, change of school appears to be more common when students are about to enter the final class (i.e. SSIII) as some of them may prefer to write their external exams elsewhere. Furthermore, $27.4 \%$ of the respondents belonged to boys' schools, $30 \%$ belonged to girls' schools, while $42.6 \%$ belonged to coeducational schools. The preponderance of coeducational schools is to be accounted for by the fact that more coeducational schools were selected for the study given the non-availability of boys-alone and/or girls-alone schools in some of the areas studied. Lastly, while $59 \%$ of the respondents attended urban schools, $41 \%$ attended rural schools. This difference was simply for the reason that urban schools generally accommodate more students than rural schools.

Respondents' Awareness of Relevance of ICT Literacy for External Examinations

The respondents' awareness of importance of ICT literacy for external examinations was tested via three questions. Answers extracted are presented in Table 4.3 below. 
Table 3.

Respondents' Awareness of Relevance of ICT Literacy for External Examinations

\begin{tabular}{lccc}
\hline & $\begin{array}{c}\text { Do you know that JAMB } \\
\text { UTME is not done as a pen } \\
\text { and paper examination but } \\
\text { done using computer? }\end{array}$ & $\begin{array}{c}\text { Do you know that most } \\
\text { higher institutions do their } \\
\text { post-UTME test using } \\
\text { computer? }\end{array}$ & $\begin{array}{c}\text { Do you know you require some } \\
\text { computer skill to be able to write } \\
\text { these examinations done using } \\
\text { computer? }\end{array}$ \\
\hline Yes & $99 \%$ & $93.3 \%$ & $94.4 \%$ \\
No & $\mathrm{N}=618$ & $\mathrm{~N}=582$ & $\mathrm{~N}=589$ \\
No Answer & $1 \%$ & $6.7 \%$ & $3.8 \%$ \\
& $\mathrm{~N}=6$ & $\mathrm{~N}=42$ & $\mathrm{~N}=24$ \\
\hline Total & $0 \%$ & $0 \%$ & $1.8 \%$ \\
& $\mathrm{~N}=0$ & $\mathrm{~N}=0$ & $\mathrm{~N}=11$ \\
\hline
\end{tabular}

Table 3 shows that $99 \%$ of the respondent knew that JAMB UTME is not done as a pen and paper examination but done using computer, while 1\% did not know this fact. Also, while 93.3\% knew that most higher institutions do their post-UTME test using computer, $6.7 \%$ did not have this information. Similarly, $94.4 \%$ of the respondents knew that they require some computer skill to be able to write these examinations done using computer. 3.8\% did not know this fact, while 1.8\% supplied no answers to the question. These data clearly suggest that the majority of the respondents were aware of the relevance of ICT literacy to their successful participation in the external examinations awaiting them in the future. This would imply that ignorance will not likely be a factor in whatever attitude the respondents may adopt towards acquiring ICT literacy in readiness for these exams.

\section{Respondents' Acquisition of ICT Literacy in Readiness for Examinations}

The respondents' possession of ICT skills in readiness for computer-based examinations was tested. In the process, data were collected in regard to their acquistion of ICT training, on whether their acqusition of the training was related to computer-based examinations, on whether and how soon they planned to go for ICT training (if they have not), and lastly on whether their ICT skills are enough for participation in CBTs. The results are presented in Table 4.4 below.

Table 4.

Respondents' Acquisition of Computer Training

\begin{tabular}{lcc}
\hline & Frequency & Percentage \\
\hline Yes & 357 & $57.2 \%$ \\
No & 287 & $42.8 \%$ \\
\hline Total & $\mathbf{6 2 4}$ & $\mathbf{1 0 0 . 0 \%}$ \\
\hline
\end{tabular}

Table 4 shows that $57.2 \%$ of the respondents had received computer training, while $42.8 \%$ had not. Thus, while the majority had acquired the training, a significant number were yet to do so. Perhaps, this situation may be attributable to the low level of computer access and training in public secondary schools in Nigeria as established by several recent studies including (Ogwo, Maidoh \& Onwe, 2015; Nijoku \& Oriaku, 2016; Ene, 2011).Basically, these studies found that public secondary schools are generally inferior to their private counterparts in terms of availability of computer facilities, computer teachers and actual offering of ICT training.

Table 5.

Respondents' Responses As to Whether their Decision to Acquire Computer Training was Informed by Anticipation of Writing Computer-Based Examinations in Future

\begin{tabular}{lcc}
\hline & Frequency & Percentage \\
\hline My decision was wholly informed by it & 69 & $11 \%$ \\
My decision was partly informed by it & 147 & $23.6 \%$ \\
My decision was never informed by it & 116 & $18.6 \%$ \\
No Answer & 292 & $46.8 \%$ \\
\hline Total & $\mathbf{6 2 4}$ & $\mathbf{1 0 0 . 0 \%}$ \\
\hline
\end{tabular}

Table 5. shows that $11 \%$ of the respondents said their decision to acquire computer training was wholly informed by their anticipation of writing computer-based tests in future, $23.6 \%$ said theirs was partly informed by it, while $18.6 \%$ said their decision had nothing to do with this. Thus, a total of $34.7 \%$ of the respondents decided to acquire computer training wholly or partly in anticipation of future CBTs. When the number that supplied no answer is eliminated, then some $65 \%$ had their decision informed by their anticipation of such examinations. By implication, even though a large number failed to acquire computer training, majority of those that acquired were fully or partly motivated by their knowledge that they would write computer-based 
examinations in future.

Table 6.

Respondents' Plans to Acquire Computer Training

\begin{tabular}{lcc}
\hline & Frequency & Percentage \\
\hline Soon & 198 & $31.7 \%$ \\
Sometime in the Future & 55 & $8.8 \%$ \\
Never & 11 & $1.8 \%$ \\
No Answer & 360 & $57.7 \%$ \\
\hline Total & $\mathbf{6 2 4}$ & $\mathbf{1 0 0 . 0 \%}$ \\
\hline
\end{tabular}

Table 6 shows that $31.7 \%$ of the respondents had plans to acquire computer training in the future, $8.8 \%$ planned to have it sometime in the future, while $1.8 \%$ said they never planned such. If the number that had acquired computer training (Table 4.4) is eliminated, then it will be seen that majority $(88.2 \%)$ of the respondents without computer training planned to acquire it soon or sometime in the future. This agrees with findings of previous studies to the effect that young people are increasingly having interest in the ICTs and generally willing to acquire the skills (Mabayoje, Isah, Bajeh \& Oyekunle, 2015; Ukommi \& Okeagu, 2015; Ene , 2011).

Table 7.

Respondents' Possession of Enough Computer Skills for Writing CBT

\begin{tabular}{lcc}
\hline & Frequency & Percentage \\
\hline To a large extent & 36 & $5.8 \%$ \\
To some extent & 146 & $23.4 \%$ \\
To a little extent & 155 & $24.8 \%$ \\
Not at all & 262 & $42.0 \%$ \\
No Answer & 25 & $4.0 \%$ \\
\hline Total & $\mathbf{6 2 4}$ & $\mathbf{1 0 0 . 0 \%}$ \\
\hline
\end{tabular}

Table 7 shows that $5.8 \%$ of the respondents "to a large extent" possessed enough computer skills to write computer-based tests, $23.4 \%$ possessed this "to some extent", $24.8 \%$ possessed these skills "to a little extent", while $42 \%$ supplied no answers to the question. On the whole therefore, $54 \%$ of the respondents, to varying extents, possessed such skills, representing about $94 \%$ of the number that have acquired computer training. Thus, instructively, students' acquisition of computer training appeared to have proven useful in terms of equipping them with enough skills for writing CBTs.

\section{Factors Affecting Respondents' Possession of Enough Computer Skills for Writing Computer-Based Test (CBT)}

Factors that affected respondents' possession of enough computer skills for writing computer-based test (CBT) were tested. Thus, seven independent variables were cross-tabulated with this dependent variable i.e. gender, age, class, type of school, location of school, availability of school-based computer training, and availability of computers at home. These are found in Table 8 to 13 below.

\section{Table.8.}

Influence of Gender on Respondents' Possession of Enough Computer Skills for Writing Computer-Based Test (CBT)

\begin{tabular}{lccc}
\hline Respondents' Possession $\begin{array}{c}\text { of } \\
\text { Enough Computer Skills for }\end{array}$ & \multicolumn{2}{c}{ Respondents' Gender } & Total \\
Writing CBT & Male & Female & \\
\hline To a large extent & $6.8 \%$ & $5.4 \%$ & $6 \%$ \\
& $\mathrm{~N}=18$ & $\mathrm{~N}=18$ & $\mathrm{~N}=36$ \\
To some extent & $29.2 \%$ & $20.6 \%$ & $24.4 \%$ \\
& $\mathrm{~N}=77$ & $\mathrm{~N}=69$ & $\mathrm{~N}=146$ \\
To a little extent & $25.4 \%$ & $26.3 \%$ & $25.9 \%$ \\
& $\mathrm{~N}=67$ & $\mathrm{~N}=88$ & $\mathrm{~N}=155$ \\
Not at all & $36.6 \%$ & $47.8 \%$ & $43.7 \%$ \\
& $\mathrm{~N}=102$ & $\mathrm{~N}=160$ & $\mathrm{~N}=262$ \\
\hline Total & $\mathbf{1 0 0 \%}$ & $\mathbf{1 0 0 \%}$ & $\mathbf{1 0 0 \%}$ \\
& $\mathbf{N = \mathbf { 2 6 4 }}$ & $\mathbf{N = 3 3 5}$ & $\mathbf{N}=\mathbf{5 9 9}$ \\
\hline
\end{tabular}

$\mathrm{X}^{2}=7.817 ; \mathrm{df}=3 ; \mathrm{p}<.0 .050$

Data in Table 8 show that male respondents tended to possess enough computer skills for computer-based tests more than their female counterparts. This was found to be statistically significant at 0.50 level. Thus, male students were more likely to be prepared for CBTs than their female counterparts. However, both Sanni and 
Mohammad (2015) and Adebowale et al. (2010) found that female students tend to show more interest in CBTs than male students. If this interest would translate to possession of skill, then this will contradict the finding of the present study. Nonetheless, it should be noted that the two cited studies were situated in the South-West Nigeria, the present one is situated in a different region - South-East, precisely Anambra State.

\section{Table 9.}

Influence of Age on Respondents' Possession of Enough Computer Skills for Writing Computer-Based Test (CBT)

\begin{tabular}{|c|c|c|c|}
\hline \multirow{2}{*}{$\begin{array}{l}\text { Respondents' Possession of } \\
\text { Enough Computer Skills for } \\
\text { Writing CBT }\end{array}$} & \multicolumn{2}{|c|}{ Respondents' Age Bracket } & \multirow[t]{2}{*}{ Total } \\
\hline & $14-17$ & 18 and above & \\
\hline \multirow[t]{2}{*}{ To a large extent } & $6.5 \%$ & $3.7 \%$ & $6 \%$ \\
\hline & $\mathrm{N}=32$ & $\mathrm{~N}=4$ & $\mathrm{~N}=36$ \\
\hline \multirow[t]{2}{*}{ To some extent } & $22.4 \%$ & $33.6 \%$ & $24.4 \%$ \\
\hline & $\mathrm{N}=110$ & $\mathrm{~N}=36$ & $\mathrm{~N}=146$ \\
\hline \multirow[t]{2}{*}{ To a little extent } & $28.9 \%$ & $12.1 \%$ & $25.9 \%$ \\
\hline & $\mathrm{N}=142$ & $\mathrm{~N}=13$ & $\mathrm{~N}=155$ \\
\hline \multirow[t]{2}{*}{ Not at all } & $42.3 \%$ & $50.5 \%$ & $43.7 \%$ \\
\hline & $\mathrm{N}=208$ & $\mathrm{~N}=54$ & $\mathrm{~N}=262$ \\
\hline Total & $100 \%$ & $\begin{array}{c}100 \% \\
\end{array}$ & $\begin{array}{c}100 \% \\
\end{array}$ \\
\hline
\end{tabular}

$\mathrm{X}^{2}=16.546 ; \mathrm{df}=3 ; \mathrm{p}<.0 .001$

Table 9 shows that respondents of lower ages $(14-17$ years) tended to possess enough computer skills for computer-based tests more than their counterparts of higher ages (18 years and above). This was found to be statistically significant at 0.001 level. This appears unlikely given that students of higher ages are likely to be in the higher class (SS3) and so closer to external examinations and therefore expected to be better prepared than their counterparts below them in class. Incidentally, Sanni and Mohammad (2015) also found age to be an active variable in students' attitude to computer-based examinations.

Table10.

Influence of Class on Respondents' Possession of Enough Computer Skills for Writing Computer-Based Test (CBT)

\begin{tabular}{lccc}
\hline Respondents' Possession of Enough & \multicolumn{2}{c}{ Respondents' Class } & \multirow{2}{*}{ Total } \\
\cline { 2 - 3 } Computer Skills for Writing CBT & $\mathrm{SS} 2$ & $\mathrm{SS} 3$ & $6 \%$ \\
\cline { 2 - 3 } To a large extent & $7.5 \%$ & $4.2 \%$ & $\mathrm{~N}=36$ \\
To some extent & $\mathrm{N}=25$ & $\mathrm{~N}=11$ & $24.4 \%$ \\
& $26.3 \%$ & $21.9 \%$ & $\mathrm{~N}=146$ \\
To a little extent & $\mathrm{N}=88$ & $\mathrm{~N}=58$ & $25.9 \%$ \\
& $24.9 \%$ & $27.2 \%$ & $\mathrm{~N}=155$ \\
Not at all & $\mathrm{N}=83$ & $\mathrm{~N}=72$ & $43.7 \%$ \\
& $41.3 \%$ & $46.8 \%$ & $\mathrm{~N}=262$ \\
\hline Total & $\mathrm{N}=138$ & $\mathrm{~N}=124$ & $\mathbf{1 0 0 \%}$ \\
& $\mathbf{1 0 0 \%}$ & $\mathbf{1 0 0 \%}$ & $\mathbf{N}=\mathbf{5 9 9}$ \\
\hline
\end{tabular}

$\mathrm{X}^{2}=5.259 ; \mathrm{df}=3 ; \mathrm{p}<.0 .157$

Table 10 shows that respondents in the lower class (SS2) tended to possess enough computer skills for computer-based tests more than their counterparts in higher classes (SS3). However, this was found not to be statistically significant. In other words, the students' level of study is not a significant determiner of their preparedness for computer-based examinations. As stated earlier, this appears to go contrary to what should be the ideal situation, which is that students should be better prepared as they advance in class as computer-based external examinations become nearer to them. 
Table 11.

Influence of Type of School on Respondents' Possession of Enough Computer Skills for Writing Computer-Based Test (CBT)

\begin{tabular}{|c|c|c|c|c|}
\hline \multirow{2}{*}{$\begin{array}{l}\text { Respondents' Possession of Enough } \\
\text { Computer Skills for Writing CBT }\end{array}$} & \multicolumn{3}{|c|}{ Type of School } & \multirow[t]{2}{*}{ Total } \\
\hline & Boys' School & Girls' School & $\begin{array}{l}\text { Coeducational } \\
\text { School }\end{array}$ & \\
\hline \multirow[t]{2}{*}{ To a large extent } & $6.2 \%$ & $2.3 \%$ & $8.3 \%$ & $6 \%$ \\
\hline & $\mathrm{N}=10$ & $\mathrm{~N}=4$ & $\mathrm{~N}=22$ & $\mathrm{~N}=36$ \\
\hline \multirow[t]{2}{*}{ To some extent } & $37.3 \%$ & $26.2 \%$ & $15.4 \%$ & $24.4 \%$ \\
\hline & $\mathrm{N}=60$ & $\mathrm{~N}=45$ & $\mathrm{~N}=41$ & $\mathrm{~N}=146$ \\
\hline \multirow[t]{2}{*}{ To a little extent } & $36.6 \%$ & $39.5 \%$ & $10.5 \%$ & $25.9 \%$ \\
\hline & $\mathrm{N}=59$ & $\mathrm{~N}=68$ & $\mathrm{~N}=28$ & $\mathrm{~N}=155$ \\
\hline \multirow[t]{2}{*}{ Not at all } & $19.9 \%$ & $32 \%$ & $65.8 \%$ & $43.7 \%$ \\
\hline & $\mathrm{N}=32$ & $\mathrm{~N}=55$ & $\mathrm{~N}=175$ & $\mathrm{~N}=262$ \\
\hline \multirow[t]{2}{*}{ Total } & $100 \%$ & $100 \%$ & $100 \%$ & $100 \%$ \\
\hline & $N=161$ & $N=172$ & $N=266$ & $N=599$ \\
\hline
\end{tabular}

$\mathrm{X}^{2}=125.935 ; \mathrm{df}=6 ; \mathrm{p}<.0 .000$

Data in Table 11 show that respondents attending boys' schools or girls' schools tended to possess enough computer skills for computer-based tests more than their counterparts in coeducational schools. This was found to be statistically significant at 0.000 level. Perhaps, this is explainable by the fact that more coeducational schools were selected from rural areas than boys' or girls' schools.

\section{Table 12.}

Influence of School Location Respondents' Possession of Enough Computer Skills for Writing ComputerBased Test (CBT)

\begin{tabular}{lccc}
\hline Respondents' Possession $\begin{array}{c}\text { of } \\
\text { Enough Computer Skills for }\end{array}$ & \multicolumn{2}{c}{ Location of School } & Total \\
Writing CBT & Urban & Rural & \\
\hline To a large extent & & & $6 \%$ \\
& $\mathrm{~N}=1 \%$ & $\mathrm{~N}=22$ & $\mathrm{~N}=36$ \\
To some extent & $30 \%$ & $16.8 \%$ & $24.4 \%$ \\
& $\mathrm{~N}=103$ & $\mathrm{~N}=43$ & $\mathrm{~N}=146$ \\
To a little extent & $39.9 \%$ & $7 \%$ & $25.9 \%$ \\
& $\mathrm{~N}=137$ & $\mathrm{~N}=18$ & $\mathrm{~N}=155$ \\
Not at all & $25.9 \%$ & $32 \%$ & $43.7 \%$ \\
& $\mathrm{~N}=89$ & $\mathrm{~N}=67.6$ & $\mathrm{~N}=262$ \\
\hline Total & $\mathbf{1 0 0 \%}$ & $\mathbf{1 0 0 \%}$ & $\mathbf{1 0 0 \%}$ \\
& $\mathbf{N = 3 4 3}$ & $\mathbf{N}=\mathbf{2 5 6}$ & $\mathbf{N = 5 9 9}$ \\
\hline
\end{tabular}

$\mathrm{X}^{2}=134.938 ; \mathrm{df}=3 ; \mathrm{p}<.0 .000$

Data in Table 12 show that respondents attending urban schools tended to possess enough computer skills for computer-based tests more than their counterparts in rural schools. This was found to be statistically significant at 0.000 level. This finding could be understood against the backdrop of the fact that urban dwellers are generally better placed socio-economically; so children of urban homes are more likely to have access to computer facilities and training than their rural counterparts. Similarly, urban schools are more likely to be better equipped with ICT facilities and ICT teachers than rural schools. Ubulom and Wokocha (2012) had, in a similar study, found that the level of readiness and acceptability regarding computer-based examination was higher in students of urban schools than students of rural schools. 
Table 13.

Influence of School-Based Computer Training on Respondents' Possession of Enough Computer Skills for Writing Computer-Based Test (CBT)

\begin{tabular}{lccc}
\hline Respondents' Possession of Enough & \multicolumn{2}{c}{ Does your school offer } & \multirow{2}{*}{ Total } \\
Computer Skills for Writing CBT & computer training to students? & \\
\cline { 2 - 3 } To a large extent & Yes & No & $6 \%$ \\
& $8.8 \%$ & $2 \%$ & $\mathrm{~N}=36$ \\
To some extent & $\mathrm{N}=31$ & $\mathrm{~N}=5$ & $24.4 \%$ \\
& $31.3 \%$ & $\mathrm{~N}=36$ & $\mathrm{~N}=146$ \\
To a little extent & $\mathrm{N}=110$ & $23.5 \%$ & $25.9 \%$ \\
& $27.6 \%$ & $\mathrm{~N}=58$ & $\mathrm{~N}=155$ \\
Not at all & $\mathrm{N}=97$ & $148 \%$ & $43.7 \%$ \\
& $32.4 \%$ & $\mathrm{~N}=59.9$ & $\mathrm{~N}=262$ \\
\hline Total & $\mathrm{N}=114$ & $\mathbf{1 0 0 \%}$ & $\mathbf{1 0 0 \%}$ \\
& $\mathbf{1 0 0 \%}$ & $\mathbf{N}=\mathbf{2 5 6}$ & $\mathbf{N}=\mathbf{5 9 9}$ \\
\hline
\end{tabular}

$\mathrm{X}^{2}=53.756 ; \mathrm{df}=3 ; \mathrm{p}<.0 .000$

Data in Table 13 show that respondents whose schools offered computer training tended to possess enough computer skills for computer-based tests more than their counterparts in schools that did not. This was found to be statistically significant at 0.000 level. This suggests that school-based computer training is an important factor in the acquisition of requisite skills for computer-based examinations. Previous studies by Njoku and Oriaku (2016) and Mabayoje et al. (2015) found a similar correlation between school-based computer training and possession of ICT skills among students. Precisely, Njoku and Oriaku (2016) found that inadequacy in facilities and personnel for computer training in school negatively affected computer literacy level among students, especially in rural schools.

Table 14.

Influence of Availability of Computer At Home on Respondents' Possession of Enough Computer Skills for Writing Computer-Based Test (CBT)

\begin{tabular}{|c|c|c|c|}
\hline \multirow{2}{*}{$\begin{array}{l}\text { Respondents' Possession of } \\
\text { Enough Computer Skills for }\end{array}$} & \multicolumn{2}{|c|}{ Is there a computer at your home? } & \multirow[t]{2}{*}{ Total } \\
\hline & Yes & No & \\
\hline \multirow[t]{2}{*}{ To a large extent } & $10.9 \%$ & $4.7 \%$ & $6 \%$ \\
\hline & $\mathrm{N}=15$ & $\mathrm{~N}=21$ & $\mathrm{~N}=36$ \\
\hline \multirow{2}{*}{ To some extent } & $26.1 \%$ & $24.4 \%$ & $24.8 \%$ \\
\hline & $\mathrm{N}=36$ & $\mathrm{~N}=110$ & $\mathrm{~N}=146$ \\
\hline \multirow[t]{2}{*}{ To a little extent } & $11.6 \%$ & $29.6 \%$ & $25.3 \%$ \\
\hline & $\mathrm{N}=16$ & $\mathrm{~N}=133$ & $\mathrm{~N}=149$ \\
\hline \multirow[t]{2}{*}{ Not at all } & $51.4 \%$ & $41.3 \%$ & $43.7 \%$ \\
\hline & $\mathrm{N}=71$ & $\mathrm{~N}=186$ & $\mathrm{~N}=257$ \\
\hline Total & $\begin{array}{c}100 \% \\
N=138\end{array}$ & $\begin{array}{c}100 \% \\
N=450\end{array}$ & $\begin{array}{c}100 \% \\
N=588\end{array}$ \\
\hline
\end{tabular}

$\mathrm{X}^{2}=22.670 ; \mathrm{df}=3 ; \mathrm{p}<.0 .000$

Data in Table 14 show that respondents who had computer at home tended to possess enough computer skills for computer-based tests more than their counterparts who did not have. This was found to be statistically significant at 0.000 level. This suggests that availability of computer at home enhanced computer training and practice among the students. This agrees with the finding by Ene (2011) that availability of computer facilities at home influenced ICTs literacy level among the students.

\section{Focus Group Discussion (FGD) Data}

The results of the three focus group discussion (FGD) sessions are presented in this section. The The responses generated via the sessions were transcribed. The researcher critically read the transcripts bearing in mind the objectives of the study. This reading revealed a number of emerging themes as follows:

i. Participants' Awareness of Relevance of ICT Literacy for External Examinations

ii. Participants' Acquisition of ICT Literacy in Readiness for Examinations

iii. Factors Affecting Participants' Readiness for CBT

\section{Participants' Demographics}

The researcher purposively selected the FGD participants to reflect the demographics relevant to the study. Thus, 9 participants were male while nine were female, nine were 14 to 17 years old while nine were 18 years and 
above. Also, nine of the participants were in SSII while nine were in SSIII. Similarly, six participants were selected each from a boys' school, a girls' school and a coeducational school. Twelve (12) of the participants were of urban schools, six (6) were of rural schools. This discrepancy resulted from the fact that two out of the three FGD sessions were held at urban schools given that urban schools were generally of larger populations, so constituted much of the research population.

\section{Participants' Awareness of Relevance of ICT Literacy for External Examinations}

The participants generally showed awareness of the fact that some external examinations they were to take in the future are computer-based and so requires ICT literacy. JAMB UTME was the examination the students were mostly conversant with in terms of being computer-based. A few of them also mentioned that they knew that post-UTME examinations organized by universities are usually computer-based. Participant 4, for instance, said: I know some of these exams we will write after here are done on computer. I have seen it once when I accompanied my sister to her JAMB mock examination last year. I know I am going to face such in future since that is the only way it is done (Group 1, male, 18).

Instructively, only Participant 14 (male, 17 years) admitted not to be aware of such computer-based examinations. Nonetheless, this is not to say that all the other participants who said they were aware of such examinations actually understood what they imply. While majority understood that questions are administered and answered through computer sets, a few admitted that they did not understand exactly how such a system works. For instance, Participant 16 stated:

I have been hearing of people writing examinations using computer. I know it is called CBT, but honestly I am yet to figure out exactly how it works. Sometimes, I wonder how it is; is it exactly like the normal exams we do where? Or is there something special about it? How do the questions come out and how does one answer them? This has increased my keenness to experience this sort of examination, I can't wait. At the same time, it has made me grown nervous wondering whether I can really cope with this sort of examination (Group 3, female, 16 years).

What may be said here is that such participants merely have the awareness but lack the knowledge of computer-based examinations. While awareness and knowledge can, in certain contexts, be used interchangeably, there is, however, a distinction between the two. Awareness means being conscious of a phenomenon, knowledge refers to facts, information and skills about the phenomenon which are acquired through experience or education. Thus, the key difference is that while knowledge is associated with deep understanding and familiarity with a subject, awareness does not imply a deep understanding (De Vries\&Mudde, 2008).

Importantly, there appeared to be no noticeable difference in the level of awareness between participants in urban and those in rural schools. This suggests that as far as awareness of computer-based examinations is concerned, rural-urban divide did not significantly play a role. However, it is still noteworthy that the only respondent who admitted ignorance of this sort of examination was from the only rural school that participated in the FGD.

The participants were further invited to say whether they were aware that they require some computer skill to be able to write this sort of examination. The answer was unanimously in the affirmative. It appeared that their awareness that this sort of examination is done on computer naturally translated to their being aware that they required computer skills to be able to participate in it. Interestingly, even the participants who admitted not to understand exactly how a CBT examination looks like still stated that they were aware that they require computer skill to be able to do so. Participant 11, for example, said:

Even though I don't really know how this computer(-based) exam is done, I know one can't just go into it without learning how to operate (the) computer. Since one does not write the exam using pen, you need to be trained on how to do this one. Your knowing how to write with pen is not enough (Group 3, female, 18 years).

Thus, the participants could be said to generally know that ICT skill is crucial to one's effective participation in computer-based tests (CBTs). This aligns with the survey data in Table 4.3 which indicate that majority of the respondents were aware of the relevance of ICT literacy to their successful participation in the external examinations awaiting them in the future.

\section{Participants' Acquisition of ICT Literacy in Readiness for Examinations}

While some of the participants said they had or were currently undergoing computer training, others gave negative answers. On the whole, twelve of the participants, just a little over half, said they had or were acquiring such training. This survey data in Table 4.4 indicate that $57.4 \%$ of the respondents had acquired computer training. Thus, both the FGD and survey revealed low rate of computer training among the students. In "a world where computer and other ICTs are becoming indispensable 


\section{Analysis of Research Questions}

Research Question 1:To what extent are students in public secondary schools in Anambra State aware of the relevance of ICT literacy for their external examinations?

To answer this research question, reference is made to Table 3 which shows that the majority of the respondents were aware that JAMB UTME (99\%) and post-UTME tests of most higher institutions (93.3\%) are written as CBT. Majority (94.4\%) were also aware that to participate in such examinations, one requires ICT literacy. The FGD data also indicates that participants generally displayed awareness of the reality that some external examinations they were to take in the future are computer-based and so requires ICT literacy. Based on the foregoing, the first research question is answered by stating that, to a significant extent, students in public secondary schools in Anambra State were aware of the relevance of ICT literacy for their participation in external examinations.

\section{Research Question 2: How much have the students taken steps to acquire ICT literacy in readiness for the examinations?}

To answer this research question, reference is made to Tables 4 to 6 . Data in Table 4 indicate that while the majority had acquired the training, a significant number $(42.8 \%)$ were yet to do so. Table 5 shows that even though a large number failed to acquire computer training, majority $(65 \%)$ of those that acquired were fully or partly motivated by their knowledge that they would write computer-based examinations in future. Data in Table 6 indicate that majority $(88.2 \%)$ of the respondents without computer training planned to acquire it soon or sometime in the future. The FGD data also revealed that a little over half of the participants admitted not to have undergone or were undergoing computer training in readiness for such computer-based examinations. All this indicates that close to $50 \%$ of the respondents were yet to undergo and were not undergoing computer training. Consequently, it may be stated in answer to the second research question that a significant number of students of public secondary schools in Anambra State were yet to take steps to acquire ICT literacy in readiness for the computer-based tests (CBTs).

\section{Research Question 3: What proportion of the students has already acquired the ICT literacy needed for} the external examinations?

To answer this research question, reference is made to Table 7 showing that about half (54\%) of the respondents, to varying extents, possessed computer skills to write CBT. Thus, close to half did not possess such skills, which implies that close to 50\% were not yet prepared for the examinations. The FGD data also reveal a similar low pattern as many of the participants admitted not to possess the required skills for such computer-based examinations. In other words, if there were to be such examination at that time, close to half would not be able to write it due simply to lack of the requisite ICT skill. Therefore, it may be stated in answer to the third research question that the rate of readiness for the computer-based tests in terms of ICT literacy was low among the students.

\section{Research Question 4: What factors enhance or hinder the students' acquisition of such ICT literacy?}

To answer this research question, reference was made to Tables 8 to 14. Data in Table 8 show that male respondents tended to possess enough computer skills for computer-based tests more than their female counterparts, and which was found to be statistically significant at 0.50 level. Table 9 shows that respondents of lower ages (14 - 17 years) tended to possess enough computer skills for computer-based tests more than their counterparts of higher ages (18 years and above), and which was found to be statistically significant at 0.001 level. Table 10 shows that respondents in the lower class (SS2) tended to possess enough computer skills for computer-based tests more than their counterparts in higher classes (SS3). However, this was found not to be statistically significant. Data in Table 11 show that respondents attending boys' schools or girls' schools tended to possess enough computer skills for computer-based tests more than their counterparts in coeducational schools and this was found to be statistically significant at 0.000 level. Then, data in Table 12 show that respondents attending urban schools tended to possess enough computer skills for computer-based tests more than their counterparts in rural schools, and this was found to be statistically significant at 0.000 level. Similarly, Table 13 shows that respondents whose schools offered computer training tended to possess enough computer skills for computer-based tests more than their counterparts in schools that did not, and this was found to be statistically significant at 0.000 level. Lastly, data in Table 14 show that respondents who had computer at home tended to possess enough computer skills for computer-based tests more than their counterparts who did not have. This was found to be statistically significant at 0.000 level. The FGD data validated the relationship between location of school (rural versus urban) and readiness for CBT as well as between school-based computer training and readiness for $\mathrm{CBT}$ among the respondents. It also validated the relationship between availability of computer at home and readiness for CBT. From the FGD, it was further observed that a relationship existed between attending computer training offered outside the school and readiness for computer-based examinations; students 
who attended such training admitted to have acquired the skill for such examinations. Hence, it could be stated in answer to the fourth research question that factors influencing readiness for CBT among students in public secondary schools in Anambra State were gender, age, school type (boys, girls or coeducational), school location (urban versus rural), school-based computer training, availability of computer at students' homes and attending of outside-school computer coaching.

\section{CONCLUSION}

From the findings of this study, it may be inferred that many students in Anambra State public schools who participate in computer-based tests (CBTs) acquire the ICT skill required for them only after they have left school. This conclusion arises from the finding that a significant proportion of the students were yet to acquire such skill in readiness for the examinations. This situation may not be very healthy as early preparation is more likely to enhance performance better.

Furthermore, it is concluded that this study validates the argument of the Diffusion of Innovations theory especially via the finding that students of urban schools tended to be readier than their rural counterparts for computer-based tests. The theory posits that innovations (such as CBT)do not necessarily gain acceptance and use among all members of a society at the same time, but gradually diffuse among the population as influenced by some social factors. Among these factors is rural-urban divide which the theory recognizes as a predictor of familiarity and attitude to innovations - urban dwellers are more likely to get familiar with innovations earlier than rural dwellers (Rogers, 1962).

\section{Recommendations}

Based on the findings of this study, the following recommendations are deemed appropriate by the researcher: 1. School-based computer training should be enhanced by way of procurement of equipment and employment of computer literate teachers. Such will enable schools provide such training on a regular basis to students which will enhance their readiness for computer-based tests (CBTs).

2. Similarly, computer training at schools should include coaching the students on the skills required for writing computer-based tests (CBTs). This will make such trainings serve as an effective rehearsal for future CBTs by the students.

3. Particular attention should be paid to rural schools in terms of equipping public schools for offering of ICT training. This is given the finding (in this study and other studies) that rural schools are generally far less equipped than their urban counterparts for computer training, both in terms of facilities and personnel.

4. It may be necessary for schools to start exposing their students to CBT early enough by making some or part of the examinations or tests taken by them computer-based. This way, secondary schools will serve as an effective rehearsal ground for students ahead of their external CBTs.

\section{REFERENCES}

Abubakar, A. S. \& Adebayo, F. O. (2014). Using computer based test method for the conduct of examination in Nigeria: Prospects, challenges and strategies. Mediterranean Journal of Social Sciences, 5(2). 47 - 55.

Adebowale, O. F., Adewale, I. A. \&Oyeniran, F. M. (2010). Computer interest, approval and confidence of secondary school students in three selected local governments of Lagos State (Nigeria): Implications for global computerization. International Journal of Education and Development Using Information and Communication Technology, 2010, 6(1), 40 - 52.

Adepoju, O. A. (2016). An evaluation of the challenges encountered in the first general computer based test in Nigeria. PJERE, 1(1), $1-13$

Adomi, E. E. \& Kpangban, E. (2010). Application of ICTs in Nigerian secondary schools. Library Philosophy and Practice (e-journal). Paper 345

Alabi, A. T., Issa, A. O., \&Oyekunle, R. A. (2012). The use of computer based testing method for the conduct of examinations at the University of Ilorin. International Journal of Learning \& Development, 2(3), 68 - 80

Apagu, V.V \&Wakili, B. A. (2015). Availability and utilization of ICT facilities for teaching and learning of vocational and technical education in Yobe state technical colleges. American Journal of Engineering Research, 04(02), $113-118$.

Bakare, O. O. (2017). Teaching and learning ICT as a subject in Nigerian secondary schools:

The challenge of pre-service teachers' education preparation. International Journal of Digital Society (IJDS), $8(3), 1316-1323$

Davey, T. (2011). Practical considerations in computer-based testing. Retrieved from http://www.ets.org/Media/Research/pdf

De Vries, O. \&Mudde, P. I. (2008). Health communication: An introduction. Englewood Cliff, NJ: Prentice Hall.

Durojaye, D. S. \&Okon, E. O. (2015). Students' perception of computer- based test in Kogi state university: A quantitative approach. IJMIE, 5(12), $421-430$ 
Durojaye, D. S. \&Okon, E. O. (2015). Students' perception of computer- based test in Kogi state university: A quantitative approach. IJMIE, 5(12), $421-430$

Ene, O. C. (2011). ICT literacy of Nigerian secondary students: A comparative study of public and private schools. Retrieved from file://C:/Users/user/AppData/Local/Temp/telecomevolutionolawale ige 170402.pdf

Eze, R. O. \& Akubugwo, I. G. (2016). Evaluation of the integration of computer/ICT education by teachers in junior secondary schools in Nigeria: A case study of Abia state. Information and Knowledge Management, $6(7), 14-21$.

Fehintola, J. O. (2018). Assessment of challenges of CBT among students in Nigerian educational system. KIU Journal of Social Sciences, 4(2), 141-149.

Griffin R.W. (2000). The media theory. New York: McGraw-Hill.

Ifejiofor, A. P. \& Nwankwo, C. A. (2015). The undercurrents of ICT skill acquisition in Nigeria: problems and prospects. International Journal of Research in Business Studies and Management, 2(8), 1-7

Ikwuka, O. I., Obumneke-Okeke, I. M., Okeke, C. C. \&Adigwe, J. E. H. (2017) Assessment of teachers' literacy of instructional value and use of ICT in secondary schools in Nnewi education zone. Journal of Emerging Trends in Educational Research and Policy Studies (JETERAPS), 8(6), 327 - 331.

Internet World Stats (2019). Internet users in Africa 2017. Retrieved from http://www.internetworldstats.com/stats1.htm

Joint Admissions and Matriculation Board, JAMB (2015). Application statistics. Retrieved from http://www.jamb.gov.ng/DOPDF/2015\% 20APP\%20STAT.pdf

Joshua, M. T. \& Ikiroma, B. (2016). Computer-based testing in Nigeria's university entrants' matriculation examination: Readiness and acceptability of critical stakeholders.

Mabayoje, M. A., Isah, A., Bajeh, A. O. \&Oyekunle, R. A. (2015). An assessment of ICT literacy among secondary school students in a rural area of Kwara state, Nigeria: A community advocacy approach. Covenant Journal of Informatics and Communication Technology, 3(1), 40 - 53.

Njoku, C. C. \&Oriaku, C. A. (2016). Hands-on computer education: A pre-condition for successful implementation of computer-based test (CBT) examinations in Nigerian secondary schools. Journal of Assertiveness, 10(1), $21-32$.

Nwanze, M. Z. (2014). Strategies for improving computer studies in secondary schools in Oshimili and Aniocha local government area of Delta state (Master's thesis, University of Nigeria, Nsukka). Retrieved fromRetrieved from https://educationconference.co/wp-content/uploads/2018/03/15.-Ugwu-UgochiUkamaka.pdf

Okocha, F., Toluwani, T. E. \&Owolabi, S. (2017). Student perception and acceptance of computer based testing: A case study of Landmark University students. Journal of Digital Innovations \&Contemp Res. In Sc., Eng\& Tech, 5(1), $25-32$.

Okoronkwo, C. (2015, April 29). Appraising JAMB's computer-based test. News Agency of Nigeria. Retrieved from www.nannewsnigeria.com/

Onyibe, C. O., Nwachi-Ikpor, J. O. \&Abdulhakim, A. A. (2015). Computer Based Testing Technique in Nigeria: Prospects and Challenges. Journal of Information Engineering and Applications, 5(10), 17 - 21.

Osunwusi, A. O. \& Abifarin, M. S. (2013). A comparative assessment of computer literacy of private and public secondary school students in Lagos State, Nigeria. Educational Research and Reviews, 8(12), $881-889$.

Rogers, D. (1962). Understanding diffusion of innovation. London: Pluto.

Sanni, A. A. \& Mohammad, M. F. (2015). Computer Based Testing (CBT): An Assessment of Student Perception of JAMB UTME in Nigeria. Computing, Information Systems, Development Informatics \& Allied Research Journal, 6(2), 13 - 28.

Ubulom, W. J. \& Wokocha, K. (2012). Readiness and acceptability of computer-based test (CBT) for postuniversity matriculation examinations (PUME) among urban and rural senior secondary school students in Rivers State. International Journal of Innovative Social \& Science Education Research, 5(3), 51 - 60. 